UDC 636.09:591.531.2:616.995.1(477.54)

DOI: $10.31073 /$ vet_biotech38-15

PRYKHODKO YU.O. ${ }^{1,2}$, Dr Sc. (Vet. Med.), Prof., Associate Member of the NAAS, e-mail: dep_parazitology@hdzva.edu.ua,

MAZANNYY O.V..$^{1,2}$, PhD in Vet. Sc., Assistant Professor, e-mail: mazannyy78@ukr.net,

FEDOROVA O.V. ${ }^{1}, \quad \mathrm{PhD}$ in Vet. Sc., Assistant Professor, e-mail: helen1.5.1@ukr.net,

LYULIN P.V. ${ }^{1}$, PhD in Vet. Sc., Assistant Professor, e-mail: liulinpetr@gmail.com, NIKIFOROVA O.V. ${ }^{1}, \quad \mathrm{PhD}$ in Vet. Sc., Assistant Professor, e-mail: ixodes1795@gmail.com

${ }^{1}$ Kharkiv State Zooveterinary Academy

${ }^{2}$ Institute of Veterinary Medicine NAAS

\title{
ENDOPARASITES OF CARNIVORES IN NON-GOVERNMENTAL ORGANIZATION “FELDMAN ECO-PARK” (KHARKIV, UKRAINE)
}

156 feces samples from predators that belong to the Non-Governmental organization "Feldman Eco-park" (Kharkiv, Ukraine) were investigated for four years (2016-2019). Eggs/oocysts of various gastrointestinal parasites were found in 46 feces samples that made up 29.5\%. There were 13 positive samples in Caniformia (28.3\%) and 33 in Feliformia (71.7\%). All diagnosed parasitoses were caused by monoxenic (single-host) geohelminths and protozoa with a direct development cycle. The most common parasite species was Toxascaris leonina (60.9\%) followed by nematodes of the Ancylostomatidae family (19.6\%), protozoa genus Isospora (8.7\%), Toxocara cati (6.5\%) and the least common parasite was Toxocara canis (4.3\%).

Keywords: helminths, protozoa, coproscopy, predators, zoo.

Introduction. Non-Governmental organization "Feldman Eco-park" is the most visited park of the region. The number of visitors exceeds 1 million people per year.

The basis of the park is a zoo with more than 3,000 animals. Among such a variety of species mammals make up $45.8 \%$. The fauna of carnivores consists of representatives of different families: Canidae, Ursidae, Procyonidae, Mephitidae, Mustelidae, Felidae, Hyaenidae, Herpestidae. Carnivores that belong to Canidae and Felidae families are fully represented in the zoo.

The parasitofauna of carnivores in wild life is diverse and includes more than 400 species of helminths [1]. 
According to researchers from different countries, the most common parasites among carnivores both in wild life and in captivity are helminthiases of the gastrointestinal tract [2-6].

In Ukraine according to recent data, 30 species of nematodes among wild carnivores have been recorded, including 18 intestinal ones. In wild life predators are usually infested with several species of parasites. The most diverse helminth fauna was recorded in red foxes (27 species) and wolves (17 species). The extension of invasion among different representatives of Caniformia and Feliformia ranged from $46.1 \%$ to $100 \%$ [7].

The goal of the work was to carry out coproscopic studies for the diagnosis of intestinal helminths in wild carnivores of the "Feldman Eco-park".

Materials and methods. To detect helminth eggs standardized sedimentationflotation method with the application of zinc sulfate solution - 450 g per 1 liter of water (density $1.2 \mathrm{~g} / \mathrm{cm}^{3}$ ) according to A. Vishnyauskas was used.

The research technique was the following: $1 \mathrm{~g}$ of feces was thoroughly mixed with $40-50 \mathrm{ml}$ of water in the mortar. The mixture was filtered through a strainer into another dish, and the mortar was rinsed with $50-60 \mathrm{ml}$ of water for several times. Fecal matter was washed with the same water through a strainer. The obtained filtrate $(100 \mathrm{ml})$ was sedimented for 5 minutes and drained. The washing procedure was repeated twice. The sediment with $10 \mathrm{ml}$ of liquid was transferred to a centrifuge tube and was centrifuged for $1 \mathrm{~min}$ at $1500 \mathrm{rpm}$. The supernatant of the liquid was drained, and a solution of zinc sulfate was added to the sediment to the top with the formation of a meniscus of liquid above the edges of the centrifuge tube. The tube was covered with a cover glass so that the surface of the liquid could hold the glass. It was centrifuged for $0.5 \mathrm{~min}$. at $1500 \mathrm{rpm}$. At that time helminth eggs were rising and fixing to the surface of the glass. Then it was removed and transferred to a glass slide. Parasite eggs were counted at a small $(\times 100)$ magnification of the light microscope.

Differentiation of eggs and protozoa was determined according to their morphological features [8-11]. At the same time, the invasion intensity was calculated - the number of eggs in $1 \mathrm{~g}$ of feces. The invasiveness was calculated as well - the percentage of positive samples out of the total examined number.

Results of research and discussion. From 2016 to 2019 one hundred fifty six feces samples from different species of predators of two suborders: Caniformia - 74 samples and Feliformia - 82 samples from "Feldman Eco-park" (Kharkiv, Ukraine) were examined (Table 1). 


\section{Fauna of examined carnivores in Non-Governmental organization “Feldman Eco-park" (n = 156)}

\begin{tabular}{|c|c|c|}
\hline Common name & $\begin{array}{c}\text { Number } \\
\text { of samples }\end{array}$ & $\begin{array}{c}\text { Scientific name } \\
\text { (Species or Subspecies) }\end{array}$ \\
\hline \multicolumn{3}{|c|}{ Suborder Caniformia (Kretzoi, 1943) } \\
\hline \multicolumn{3}{|l|}{ Family Canidae } \\
\hline Alaska Wolf & 10 & Canis lupus pambasileus (Elliot, 1905) \\
\hline European Grey Wolf & 10 & Canis lupus lupus (Linnaeus, 1758) \\
\hline Alaskan Tundra Wolf & 10 & Canis lupus tundrarum (Miller, 1912) \\
\hline $\begin{array}{l}\text { Red Fox } \quad \text { (silver-black } \\
\text { suit) }\end{array}$ & 3 & Vulpes vulpes (Linnaeus, 1758) \\
\hline \multicolumn{3}{|l|}{ Family Ursidae } \\
\hline Brown Bear & 4 & Ursus arctos (Linnaeus, 1758) \\
\hline Asiatic Black Bear & 2 & Ursus thibetanus (G. Cuvier, 1823) \\
\hline \multicolumn{3}{|l|}{ Family Procyonidae } \\
\hline Brown-nosed Coati & 7 & Nasua nasua (Linnaeus, 1766) \\
\hline Northern Raccoon & 9 & Procyon lotor (Linnaeus, 1758) \\
\hline Raccoon Dog & 6 & Nyctereutes procyonoides (Gray, 1834) \\
\hline Ussuri Raccoon Dog & 1 & $\begin{array}{l}\text { Nyctereutes procyonoides ussuriensis (Matschie, } \\
\text { 1907) }\end{array}$ \\
\hline \multicolumn{3}{|l|}{ Family Mephitidae } \\
\hline Striped Skunk & 2 & Mephitis mephitis (Schreber, 1776) \\
\hline \multicolumn{3}{|l|}{ Family Mustelidae } \\
\hline Steppe Polecat & 8 & Mustela eversmanni (Lesson, 1827) \\
\hline Eurasian Badger & 2 & Meles meles (Linnaeus, 1758) \\
\hline \multicolumn{3}{|c|}{ Suborder Feliformia (Kretzoi, 1945) } \\
\hline \multicolumn{3}{|l|}{ Family Felidae } \\
\hline Bengal Tiger & 2 & Panthera tigris bengalensis (Linnaeus, 1758) \\
\hline Amur Leopard & 10 & Panthera pardus orientalis (Schlegel, 1857) \\
\hline Siberian Tiger & 6 & Panthera tigris altaica (Temminck, 1844) \\
\hline Cheetah & 16 & Acinonyx jubatus (Schreber, 1775) \\
\hline Lion & 6 & Pantera leo (Linnaeus, 1758) \\
\hline Jaguar & 5 & Panthera onca (Linnaeus, 1758) \\
\hline South African Lion & 4 & Panthera leo krugeri var. alba (Roberts 1929) \\
\hline Puma & 9 & Puma concolor (Linnaeus, 1771) \\
\hline Eurasian Lynx & 2 & Lynx lynx (Linnaeus, 1758) \\
\hline Ocelot & 2 & Leopardus pardalis (Linnaeus, 1758) \\
\hline Caracal & 4 & Caracal caracal (Schreber, 1776) \\
\hline Wildcat & 3 & Felis silvestris (Schreber, 1777) \\
\hline Leopard Cat & 3 & Prionailurus bengalensis (Kerr, 1792) \\
\hline \multicolumn{3}{|l|}{ Family Hyaenidae } \\
\hline Striped Hyena & 3 & Hyaena hyaena (Linnaeus, 1758) \\
\hline \multicolumn{3}{|l|}{ Family Herpestidae } \\
\hline Meerkat & 6 & Suricata suricatta (Schreber, 1776) \\
\hline Banded Mongoose & 1 & Mungos mungo (Gmelin, 1788) \\
\hline
\end{tabular}


The results of coproscopic studies are presented in Table 2.

Table 2

\section{Prevalence of gastrointestinal parasites in predators of Non-Governmental organization "Feldman Eco-park"}

\begin{tabular}{|c|c|c|c|c|c|c|}
\hline $\begin{array}{l}\text { Scientific } \\
\text { name }\end{array}$ & $\begin{array}{c}\text { Number } \\
\text { of } \\
\text { samples }\end{array}$ & $\begin{array}{l}\text { Toxocara } \\
\text { cati }\end{array}$ & $\begin{array}{l}\text { Toxocara } \\
\text { canis }\end{array}$ & $\begin{array}{l}\text { Toxascaris } \\
\text { leonina }\end{array}$ & $\begin{array}{c}\text { Family } \\
\text { Ancylostomatidae }\end{array}$ & $\begin{array}{c}\text { Genus } \\
\text { Isospora }\end{array}$ \\
\hline \multicolumn{7}{|c|}{ Suborder Caniformia } \\
\hline \multicolumn{7}{|c|}{ Family Canidae } \\
\hline $\begin{array}{l}\text { Canis } \\
\text { lupus }\end{array}$ & 30 & & $\begin{array}{c}2 \\
(6.7 \%)\end{array}$ & $\begin{array}{c}2 \\
(6.7 \%)\end{array}$ & $\begin{array}{c}8 \\
(26.7 \%)\end{array}$ & - \\
\hline \multicolumn{7}{|c|}{ Family Procyonidae } \\
\hline $\begin{array}{l}\text { Nasua } \\
\text { nasua }\end{array}$ & 7 & & - & - & $\begin{array}{c}1 \\
(14.3 \%)\end{array}$ & - \\
\hline \multicolumn{7}{|c|}{ Suborder Feliformia } \\
\hline \multicolumn{7}{|c|}{ Family Felidae } \\
\hline $\begin{array}{l}\text { Acinonyx } \\
\text { jubatus }\end{array}$ & 16 & $\begin{array}{c}3 \\
(18.8 \%) \\
\end{array}$ & & $\begin{array}{c}11 \\
(68.8 \%) \\
\end{array}$ & - & - \\
\hline $\begin{array}{l}\text { Pantera } \\
\text { leo }\end{array}$ & 6 & - & & $\begin{array}{c}4 \\
(66.7 \%) \\
\end{array}$ & - & - \\
\hline $\begin{array}{l}\text { Panthera } \\
\text { leo krugeri } \\
\text { var. alba }\end{array}$ & 4 & - & & $\begin{array}{c}3 \\
(75.0 \%)\end{array}$ & - & - \\
\hline $\begin{array}{l}\text { Panthera } \\
\text { pardus } \\
\text { orientalis }\end{array}$ & 10 & - & & $\begin{array}{c}2 \\
(20.0 \%)\end{array}$ & - & $\begin{array}{c}2 \\
(20.0 \%)\end{array}$ \\
\hline Lynx lynx & 2 & - & & $\begin{array}{c}2 \\
(100.0 \%)\end{array}$ & - & - \\
\hline $\begin{array}{l}\text { Puma } \\
\text { concolor }\end{array}$ & 9 & - & & $\begin{array}{c}4 \\
(44.4 \%) \\
\end{array}$ & - & - \\
\hline $\begin{array}{l}\text { Panthera } \\
\text { onca }\end{array}$ & 5 & - & & - & - & $\begin{array}{c}1 \\
(20.0 \%)\end{array}$ \\
\hline $\begin{array}{l}\text { Caracal } \\
\text { caracal }\end{array}$ & 4 & - & & - & - & $\begin{array}{c}1 \\
(25.0 \%)\end{array}$ \\
\hline Total & 93 & 3 & 2 & 28 & 9 & 4 \\
\hline
\end{tabular}

Note. In numerator - number of infected animals, and in denominator - number of infected animals expressed in percentage in relation to a number of investigated samples from the present species (subspecies) of animals.

Parasite eggs were found in 46 samples (29.5\%) out of 156 fecal samples. Among them 13 samples from Caniformia (28.3\%) and 33 samples from Feliformia (71.7\%) were positive. In general, the invasiveness of Caniformia was $17.6 \%$ and Feliformia - 40.2\%. Oocysts of protozoa genus Isospora were detected in 4 samples (2.6\%) out of all positive samples. 
Eggs/oocysts of various gastrointestinal parasites in 46 samples of feces of various carnivores were microscopically found. The most common parasite species was Toxascaris leonina (60.9\%) followed by nematodes of the Ancylostomatidae family (19.6\%), protozoa genus Isospora (8.7\%), Toxocara cati (6.5\%) and the least common parasite was Toxocara canis (4.3\%) (Fig. 1).

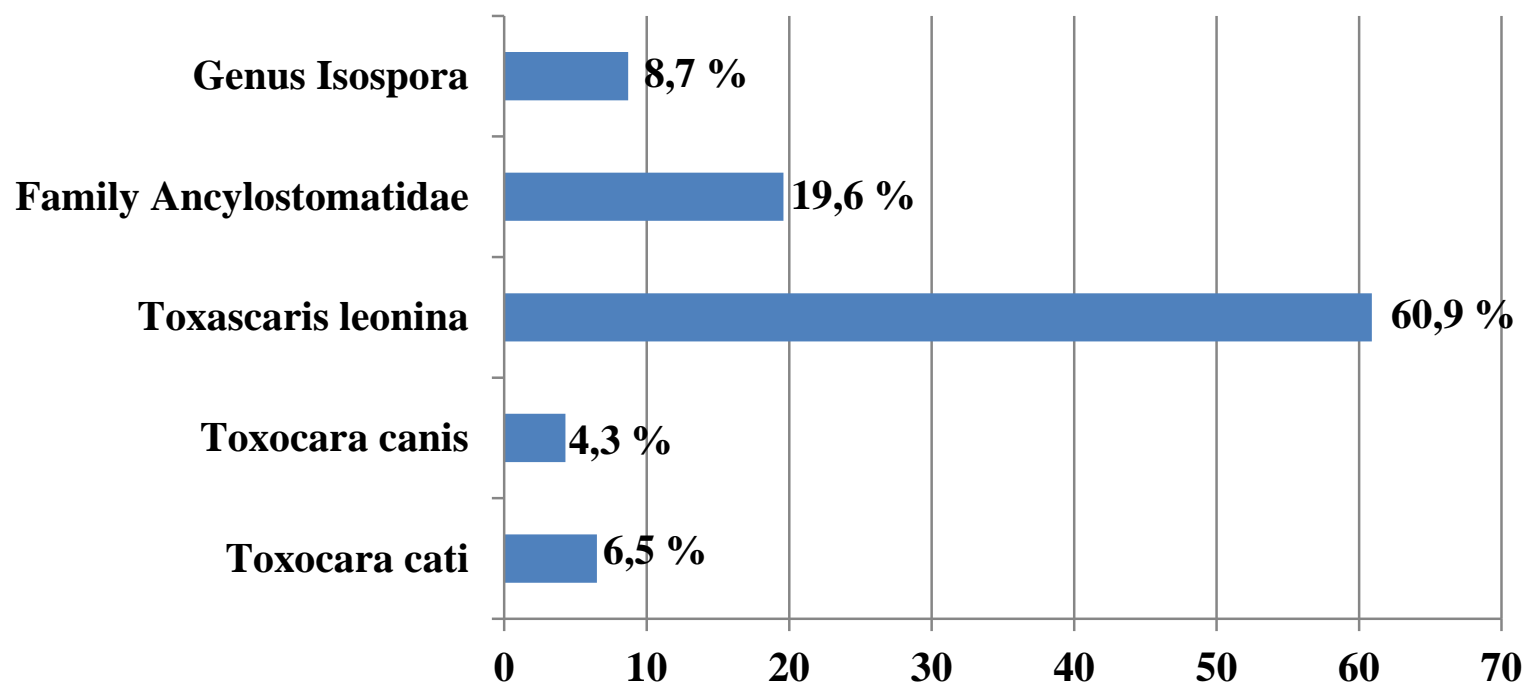

Fig. 1. Prevalence of gastro-intestinal parasites in various carnivores of NonGovernmental organization "Feldman Eco-park".

Among Caniformia only wolves and coatis were infested with nematodes. Strongilata eggs, family Ancylostomatidae were detected in $14.3 \%$ of the samples from Nasua nasua, while in wolves the number of samples infested with helminths of this family was $26.7 \%$. In addition, Toxocara canis eggs were found in $6.7 \%$ of wolves, and Toxascaris leonina eggs were detected in $6.7 \%$ of wolves.

Among Feliformia the invasiveness with toxascaris prevailed. Their eggs were found in 26 out of 82 samples, which made up 31.7\%. Toxascaris leonina eggs were found in 100\% samples from Lynx lynx, 75.0\% from Panthera leo krugeri var. alba, 68.8\% - from Acinonyx jubatus, 66.7\% - from Pantera leo, 44.4\% - from Puma concolor and $20 \%$ of samples from Panthera pardus orientalis. In three samples (18.8\%) from Acinonyx jubatus eggs genus Toxocara, Toxocara cati species were detected.

Monospecific invasions prevailed in indicated parasitoses and made up 76.9\% among invasive Caniformia (13 samples) and 6.1\% among Feliformia (33 samples).

Out of 30 samples from Canis lupus the eggs of two helminths were simultaneously detected in three samples: two samples (6.7\%) had nematodes eggs of the family Ancylostomatidae and Toxascaris leonina, and one sample (3.3\%) had nematodes eggs of the family Ancylostomatidae and Toxocara canis. 
Out of 10 samples from Panthera pardus orientalis two samples had simultaneously Toxascaris leonina eggs and genus Isospora oocysts, that made up $20 \%$.

The intensity of invasions was different and made up 37.20 \pm 17.75 eggs in $1 \mathrm{~g}$ of feces (3-101) in wolves with monoinvasion, and with mixed ones - 7.67 6 .17 (120). In Nasua nasua the intensity of invasion with Ancylostomatidae family nematodes was 0.7 eggs per gram of feces. Toxocara canis eggs were detected at a low level of invasion intensity in the amount of $0.3-1$ per $1 \mathrm{~g}$ of feces, and Toxascaris leonina eggs $-1.50 \pm 0.50$ (1-2).

In Acinonyx jubatus the invasion intensity of Toxocara cati was low $2.00 \pm 0.58$, and Toxascaris leonina - 23.45 \pm 5.36 eggs per gram of feces.

In Pantera leo the invasion intensity of Toxascaris leonina was $25.75 \pm 4.97$, in Panthera leo krugeri var. alba - 25.67 \pm 8.09 , in Panthera pardus orientalis $13.00 \pm 0.00$, in Lynx lynx $-14.00 \pm 1.00$, and in Puma concolor $-16.75 \pm 11.21$ eggs per $1 \mathrm{~g}$ of feces.

Among animals infested with isospores only invasion intensity of Panthera onca made up 15 oocysts per gram of feces, while other animals had 1-3 oocysts per gram of feces.

Discussion. Zoos play an important role in preserving wildlife biodiversity under conditions of urbanization, reducing of the habitat of the animals [12] and climate change [13].

In wild life animal populations are regulated by biotic and abiotic factors. Parasites, as biotic factors affect hosts and in combination with other conditions can cause a decrease in resistance, reproductive function, and can even lead to death of an animal $[14,15]$.

This work is devoted to the study of the parasitofauna of the gastrointestinal tract of Caniformia and Feliformia at the "Feldman Eco-Park".

According to the results of these studies, among 15 species and subspecies of the caniform suborder representatives of 2 species - wolves (Canis lupus) and coatis (Nasua nasua) were invaded by nematodes. In wolves (subspecies Canis lupus pambasileus, Canis lupus lupus, Canis lupus tundrarum) two species of geohelminths of the suborder Ascaridata (Toxocara canis, Toxascaris leonina) and one representative of the Strongylata suborder of the Ancylostomatidae family were recorded. In coatis one helminthiasis caused by a parasite from the Ancylostomatidae family was diagnosed. The extension of invasion of Caniformia by different helminths ranged from $6.7 \%$ to $26.7 \%$.

The obtained data on the distribution of pathogens of Toxocara canis, Toxascaris leonina and strongylates of the Ancylostomatidae family among wolves coincide with the data of other researchers [16]. 
Among 16 species and subspecies of the feliform suborder eight ones had nematodoses and protozoos.

At the same time, mixed two-component invasion represented by the Toxocara cati and Toxascaris leonina helminths was found in the cheetah (Acinonyx jubatus), and the Toxascaris leonina helminths and protozoa Isospora were detected in the Far Eastern leopard (Panthera pardus orientalis).

Monoinvasion caused by Toxascaris leonina helminth was registered in the African lion (Pantera leo), white lion (Panthera leo krugeri var. Alba), lynx (Lynx lynx) and puma (Puma concolor).

Monoinvasion caused by protozoa of Isospora genus was found in the jaguar (Panthera onca) and caracal (Caracal caracal).

The extension of invasion of Feliformia by helminths and protozoa ranged from $18.8 \%$ to $100 \%$.

According to the results of our research, mostly monoinvasions were recorded in predators, less often they had mixed two-component parasitoses.

Among carnivores (brown bears, lions, tigers, coatis) helminths of the suborder Ascaridata (Baylisascaris sp., Toxocara spp., Toxascaris leonina), Strongylata (Ancylostoma sp.) and Rhabditata (Strongyloides sp.) [17] were previously detected in the zoos of Dnipropetrovsk and Zaporizhzhya regions of Ukraine that mainly coincides with the data of the conducted studies.

Helminths of the Strongylata suborder are widespread in nature and are common for domestic and wild carnivores [18].

Nematodes of the Ascaridata suborder are also widespread. In this case, the species Toxocara canis is common for wild and domestic Caniformia, Toxocara cati - for Feliformia, and the species Toxascaris leonina is common for wild and domestic Caniformia and Feliformia [18].

According to the results of these studies, infestation with Toxascaris leonina species that was recorded more often among Caniformia and Feliformia reached $100 \%$.

Taking into account the results of the study and the data of other scientists, it was established that wild Caniformia and Feliformia can play an important role in the spread of parasitoses (helminthiases, protozoos) among domestic cats and dogs that can be infected from them $[19,20]$ and also become a source of zoonotic invasions [21-23].

The transmission of pathogens can be made among predators of the zoo, and among domestic and homeless carnivores. Therefore, it is necessary to carry out diagnostic studies and treatments with antiparasitic drugs systematically.

Conclusions and prospects for further research. The results of our studies showed that helminths eggs and protozoa oocysts were found in 46 samples, that is - 
29.5\% in samples of feces from predators kept in Non-Governmental organization "Feldman Eco-park". All diagnosed parasitoses were caused by monoxenic (singlehost) geohelminths and protozoa with a direct development cycle. The reasons of the circulation of these pathogens in the zoo are the following: keeping of animals on a limited area, high resistance of invasive eggs and protozoa oocysts to the external medium, the difficulties of disinvasion of the places for keeping predators, their dehelmintization, and mechanical transfer of pathogen eggs and oocysts on shoes, clothing and inventory by zoo employees.

Acknowledgements. We are grateful to the administration and specifically to the veterinary service of the Non-Governmental organization "Feldman Eco-park" for the provided biological material and technical assistance.

\section{REFERENCES}

1. Vieira, Fabiano M., Luque, José L., Muniz-Pereira, Luís C. (2008). Checklist of helminth parasites in wild carnivore mammals from Brazil. Zootaxa, 1721, 1-23. https://doi.org/10.5281/zenodo.181136.

2. Borecka, A., Gawor, J., Zieba, F. (2013). A survey of intestinal helminth sin wild carnivores from the Tatra National Park, southern Poland. Ann. Parasitol., 54(4), 169-172.

3. Dib, L.V., Cronemberger, C., Pereira, F.A., Bolais, P.F., Uchôa, C.M.A., Bastos, O.M.P., Amendoeira, M.R.R., Barbosa, A.D.C. (2018). Gastrointestinal parasites among felids inhabiting the Serra dos Órgãos National Park, Rio de Janeiro. Brazil. Revista Brasileira de Parasitologia Veterinária, 27(2), 131-140. https://doi.org/10.1590/s1984-296120180016.

4. Nasiri, V., Jameie, F. (2019). Intestinal parasitic infection in wild animals of a zoological garden in Alborz, Iran. Journal of Istanbul Veterinary Sclences, 3(2), 37-42. https://doi.org/10.30704/http-www-jivs-net.575285.

5. Panayotova-Pencheva, M.S. (2013). Parasites in captive animals: a review of studies in some European zoos. Der Zoologische Garten, 82(1-2), 60-71. https://doi.org/10.1016/j.zoolgart.2013.04.005.

6. Santos, J.L.C, Magalhães, N.B., Santos, H.Á., Ribeiro, R.R.R., Guimarães, M.P. (2012). Parasites of domestic and wild canids in the region of Serra do Cipó National Park. Brazil. Revista Brasileira de Parasitologia Veterinária, 21 (3), 270-277. https://doi.org/10.1590/S198429612012000300016.

7. Varodi, E.I., Malega, A.M., Kuzmin, Y.I., Kornyushin, V.V. (2017). Helminths of Wild Predatory Mammals of Ukraine. Nematodes. Vestnik Zoologii, 51(3), 187-202. https://doi.org/10.1515/vzoo-2017-0026.

8. Anderson, R.C. (1992). Nematode parasites of vertebrates. CAB International.

9. Kozlov, D.P. (1977). Keys to the Helminths of Predatory Mammals of the USSR. Moscow: Nauka [in Russian].

10. Thienpot, D., Rochette, F., Vanparijs, O.F.J. (1979). Diagnóstico de las helmintiasis por medio del examen coproparasitológico. Jaussen Research Foundation, Brussels [in Spain].

11. Zajac, A.M., Conboy, G.A. (2012). Veterinary clinical parasitology. ( $8^{\text {th }}$ ed.). New Jersey: US. John Wiley \& Sons. 
12. Conde, D.A., Flesness, N., Colchero, F., Jones, O.R., Scheuerlein, A. (2011). An Emerging Role of Zoos to Conserve Biodiversity. Science, 331(6023), 1390-1391. https://doi.org/10.1126/science.1200674.

13. Spindler, R., Wiszniewski, J., Slip, D. (2012). The potential role of zoos in climate change research and mitigation. Wildlife and Climate Change, 107-113. https://doi.org/10.7882/FS.2012.017.

14. Borgsteede, F.H. (1996). The effect of parasites on wildlife. The Veterinary Quarterly, 18(3), 138-140. https://doi.org/10.1080/01652176.1996.9694717.

15. Smith, K.F, Acevedo-Whitehouse, K., Pedersen, A.B. (2009). The role of infectious diseases in biological conservation. Anim. Conserv., 12(1), 1-12. https://doi.org/10.1111/j.14691795.2008.00228.x.

16. Muñoz, S., Luis, R. P., Carretón, E., Diosdado, A., González-Miguel, J., Simón, F., Morchón, R. (2018). Intestinal helminths in Iberian wolves (Canis lupus signatus) from Northwest Spain. The Open Parasitology Journal, 6, 106-111. https://doi.org/10.2174/1874421401806010106.

17. Gugosyan, YU. A., Shendryk, CH.M., Rymskii, V.V. (2018). Diversity of helminthofauna of zoo mammals. Scientific Messenger of Lviv National University of Veterinary Medicine and Biotechnologies, 20(83), 130-135. https://doi.org/10.15421/nvlvet8325.

18. Okulewicz, A., Perec-Matysiak, A., Buńkowska, K., Hildebrand, J. (2012). Toxocara canis, Toxocara cati and Toxascaris leonine in wild and domestic carnivores. Helminthologia, 49, 3-10. https://doi.org/10.2478/s11687-012-0001-6.

19. Otranto, D., Cantacessi, C., Pfeffer, M., Dantas-Torres, F., Brianti, E., Deplazes, P., Genchi, C., Guberti, V., Capelli, G. (2015). The role of wild canids and felids in spreading parasites to dogs and cats in Europe. Part I: Protozoa and tick-borne agents. Vet. Parasitol., 213, 12-3. https://doi.org/10.1016/j.vetpar.2015.04.020.

20. Otranto, D., Cantacessi, C., Dantas-Torres, F., Brianti, E., Pfeffer, M., Genchi, C., Guberti, V., Capelli, G., Deplazes, P. (2015). The role of wild canids and felids in spreading parasites to dogs and cats in Europe. Part II: helminths and arthropods. Vet. Parasitol., 213(1-2), 24-37. https://doi.org/10.1016/j.vetpar.2015.04.020.

21. Di Cerbo, A.R., Manfredi, M.T., Bregoli, M., Ferro Milone, N., Cova, M. (2008). Wild carnivores as source of zoonotic helminths in north-eastern Italy. Helminthologia, 45, 13-19. https://doi.org/10.2478/s11687-008-0002-7.

22. Otranto, D., Deplazesb, P. (2019). Zoonotic nematodes of wild carnivores. IJP: Parasites and Wildlife, 9, 370-383. https://doi.org/10.1016/j.ijppaw.2018.12.011.

23. Thompson, A.R.C., Kutz, S., Smith, A. (2009). Parasite zoonoses and wildlife: emerging issues. Int. J. Environ. Res. Publ. Health., 6, 678-693. https://doi.org/10.3390/ijerph6020678.

\section{ЭНДОПАРАЗИТЫ ПЛОТОЯДНЫХ В ОБЩЕСТВЕННОЙ ОРГАНИЗАЦИИ} «ФЕЛЬДМАН ЭКО-ПАРК» (ХАРЬКОВ, УКРАИНА) / Приходько Ю.А., Мазанный А.В., Федорова Е.В., Люлин П.В., Никифорова О.В.

За 4 года (2016-2019 гг.) происследовано 156 проб фекалий от разных видов хищников, которые принадлежали общественной организаџии «Фельдман Эко-парк» (Харьков, Украина). Яйца/оочисты различных желудочно-кишечных паразитов были обнаружены в 46 пробах фекалий, что составило 29,5\%. Среди проб от собакообразных положительных оказалось 13 (28,3\%), а от кошкообразных - 33 (71,7\%). Все 
диагностированные паразить были вызваны моноксеннылми (однохозяинньли) геогельминтами и простейшими с прямым циклом развития. Наиболее распространенным паразитом был Toxascaris leonina (60,9\%), за ним следуют нематоды семейства Ancylostomatidae (19,6\%), простейшие рода Isospora (8,7\%), Toxocara cati (6,5\%), а наименее распространенным паразитом был Тохосага саnis $(4,3 \%)$.

Ключевые слова: гельминты, простейшие, копроскопия, хищники, зоопарк.

\section{ЕНДОПАРАЗИТИ М'ЯСОӤДНИХ В ГРОМАДСЬКІЙ ОРГАНІЗАЦЇ̈} «ФЕЛЬДМАН ЕКО-ПАРК» (ХАРКІВ, УКРАЇНА) / Приходько Ю.О., Мазанний О.В., Федорова О.В., Люлін П.В., Нікіфорова О.В.

Bступ. Фауна хижих тварин ГО «Еко-парк Фельдмана» складається з представників родин: Canidae, Ursidae, Procyonidae, Mephitidae, Mustelidae, Felidae, Hyaenidae, Herpestidae. Паразитофауна хижих тварин у дикій природі включає понад 400 видів гельмінтів. Найпоширенішими серед них є гельмінти шлунково-кишкового тракту.

Метою роботи було проведення копроскопічних досліджень для діагностики кишкових гельмінтів у диких хижих тварин «Еко-парку Фельдмана».

Матеріали і методи досліджень. 3а 4 роки (2016-2019 рр.) досліджено 156 зразків фекалій від різних видів хижаків, які належать ГО «Еко-парк Фельдмана» (Харків, Україна). Копроскопічний матеріал отриманий від тварин, які відносяться до двох підрядів: собакоподібних - 74 проби $і$ кішкоподібних - 82. Для виявлення яєць гельмінтів застосовували стандартизований седиментачійно-флотаиійний метод із застосуванням розчину сульфату цинку - 450 г на 1 літр води (щуільність 1,2 г/см ${ }^{3}$ ) за А. Вишняускасом. Диференціацію яєщь та найпростіших визначали за їх морфологічними ознаками.

Результати досліджень та ӥх обговорення. Яйчя та ооцисти паразитів були виявлені в 46 зразках фекалій, щзо склало 29,5\%. Серед проб від собакоподібних позитивних виявилося 13 (28,3\%), а від кішкоподібних - 33 (71,7\%). В цілому інвазованість собакоподібних склала 17,6\%, а кішкоподібних - 40,2\%. В 4 пробах (2,6\%) були виявлені ооцисти роду Isospora. 3 собакоподібних в 14,3\% проб від Nasua паsиа виявлені яйця стронгілят родини Ancylostomatidae, а серед вовків кількість інвазованих гельмінтами даної родини склала 26,7\%. Крім цього у 6,7\% вовків виявлені яйия Tохосана canis, а ще у 6,7\% яйця Toxascaris leonina. Яйчя токсаскарисів виявлені в 26 з 82 проб від котячих, щуо склало 31,7\%. У трьох пробах (18,8\%) виявлені яйя Тохосага туstax. Моноінвазї переважали серед зазначених паразитозів і становили 76,9\%.

Інтенсивність інвазій була різною і становила у вовків при моноінвазії гельмінтами

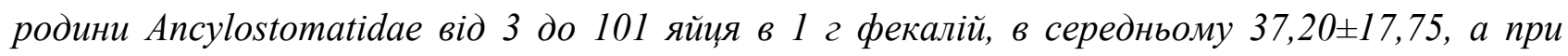

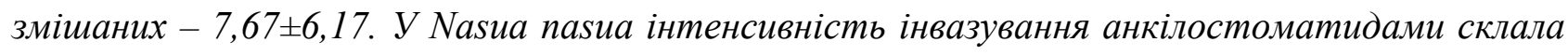
0,7 яєць в 1 г фекалій. Яйия Тохосана canis виявлені у вигляді низького (0,3-1 яйще в 1 г

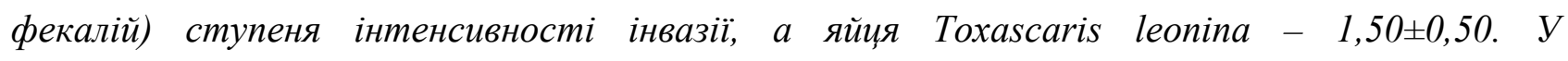

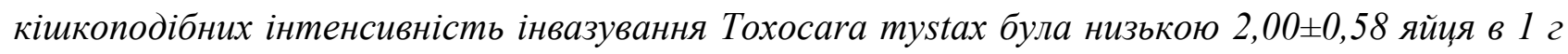

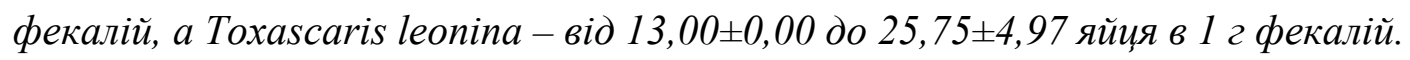

Ключові слова: гельмінти, найпростіші, копроскопія, хижаки, зоопарк. 


\section{СПИСОК ЛІТЕРАТУРИ}

1. Vieira Fabiano M. Checklist of helminth parasites in wild carnivore mammals from Brazil / Fabiano M. Vieira, José L. Luque, Luís C. Muniz-Pereira // Zootaxa. - 2008. - № 1721. P. 1-23. https://doi.org/ 10.5281/zenodo.181136.

2. Borecka A. A survey of intestinal helminth sin wild carnivores from the Tatra National Park, southern Poland / A. Borecka, J. Gawor, F. Zieba // Ann. Parasitol. - 2013. - № 54(4). P. 169-172.

3. Gastrointestinal parasites among felids inhabiting the Serra dos Órgãos National Park, Rio de Janeiro. Brazil / L.V. Dib, C. Cronemberger, F.A. Pereira [et al.] // Revista Brasileira de Parasitologia Veterinária. - 2018. - № 27(2). - P. 131-140. https://doi.org/10.1590/s1984296120180016.

4. Nasiri V. Intestinal parasitic infection in wild animals of a zoological garden in Alborz, Iran / V. Nasiri, F. Jameie // Journal of Istanbul Veterınary Sciences. - 2019. - № 3(2). - P. 37-42. https://doi.org/10.30704/http-www-jivs-net.575285.

5. Panayotova-Pencheva M.S. Parasites in captive animals: a review of studies in some European zoos / M.S. Panayotova-Pencheva // Der Zoologische Garten. - 2013. - № 82(1-2). P. 60-71. https://doi.org/10.1016/j.zoolgart.2013.04.005.

6. Parasites of domestic and wild canids in the region of Serra do Cipó National Park. Brazil / J.L.C. Santos, N.B. Magalhães, H.Á. Santos [et al.] // Revista Brasileira de Parasitologia Veterinária. - 2012. - № 21 (3). - P. 270-277. https://doi.org/10.1590/S198429612012000300016.

7. Helminths of Wild Predatory Mammals of Ukraine. Nematodes / E.I. Varodi, A.M. Malega, Y.I. Kuzmin [et al.] // Vestnik Zoologii. - 2017. - № 51(3). - P. 187-202. https://doi.org/10.1515/vzoo-2017-0026.

8. Anderson R.C. Nematode parasites of vertebrates / R.C. Anderson. - CAB International, 1992. $-578 \mathrm{p}$.

9. Козлов Д.П. Определитель гельминтов хищных млекопитающих СССР / Д.П. Козлов. - Москва, 1977. - 257 с.

10. Thienpot D. Diagnóstico de las helmintiasis por medio del examen coproparasitológico /

D. Thienpot, F. Rochette, O.F.J. Vanparijs. - Brussels: Jaussen Research Foundation, 1979. $187 \mathrm{p}$.

11. Zajac A.M. Veterinary clinical parasitology / A.M. Zajac, G.A. Conboy. $-8^{\text {th }}$ ed. - New Jersey: US. John Wiley \& Sons, 2012. - 368 p.

12. Conde D.A. An Emerging Role of Zoos to Conserve Biodiversity / D.A. Conde, N. Flesness, F. Colchero [et al.] // Science. - 2011. - № 331(6023). - P. 1390-1391. https://doi.org/10.1126/science.1200674.

13. Spindler R. The potential role of zoos in climate change research and mitigation / R. Spindler, J. Wiszniewski, D. Slip // Wildlife and Climate Change. - 2012. - P. 107-113. https://doi.org/10.7882/FS.2012.017.

14. Borgsteede F.H. The effect of parasites on wildlife / F.H. Borgsteede // The Veterinary Quarterly. - 1996. - № 18(3). - P. 138-140. https://doi.org/10.1080/01652176.1996.9694717.

15. Smith K.F. The role of infectious diseases in biological conservation / K.F. Smith, K. Acevedo-Whitehouse, A.B. Pedersen // Anim. Conserv. - 2009. - № 12(1). - P. 1-12. https://doi.org/10.1111/j.1469-1795.2008.00228.x. 
16. Intestinal helminths in Iberian wolves (Canis lupus signatus) from Northwest Spain / S. Muñoz, R.P. Luis, E. Carretón [et al.] // The Open Parasitology Journal. - 2018. - № 6. P. 106-111. https://doi.org/10.2174/1874421401806010106.

17. Gugosyan Yu. A. Diversity of helminthofauna of zoo mammals / Yu.A. Gugosyan, Ch.M. Shendryk, V.V. Rymskii // Scientific Messenger of Lviv National University of Veterinary Medicine and Biotechnologies. - 2018. - № 20(83). - P. 130-135. https://doi.org/10.15421 /nvlvet8325.

18. Okulewicz A. Toxocara canis, Toxocara cati and Toxascaris leonine in wild and domestic carnivores / A. Okulewicz, A. Perec-Matysiak, K. Buńkowska, J. Hildebrand // Helminthologia. - 2012. - № 49. - P. 3-10. https://doi.org/10.2478/s11687-012-0001-6.

19. The role of wild canids and felids in spreading parasites to dogs and cats in Europe. Part I: Protozoa and tick-borne agents / D. Otranto, C. Cantacessi, M. Pfeffer [et al.] // Vet. Parasitol. 2015. - № 213. - P. 12-23. https://doi.org/10.1016/j.vetpar.2015.04.020.

20. The role of wild canids and felids in spreading parasites to dogs and cats in Europe. Part II: helminths and arthropods / D. Otranto, C. Cantacessi, F. Dantas-Torres [et al.] // Vet. Parasitol. 2015. - № 213(1-2). - P. 24-37.

21. Wild carnivores as source of zoonotic helminths in north-eastern Italy / A.R. Di Cerbo, M.T. Manfredi, M. Bregoli [et al.] // Helminthologia. - 2008. - № 45. - P. 13-19. https://doi.org/10.2478/s11687-008-0002-7.

22. Otranto D. Zoonotic nematodes of wild carnivores / D. Otranto, P. Deplazesb // IJP: Parasites and Wildlife. - № 9. - P. 370-383. https://doi.org/10.1016/j.ijppaw.2018.12.011.

23. Thompson A.R.C. Parasite zoonoses and wildlife: emerging issues / A.R.C. Thompson, S. Kutz, A. Smith // Int. J. Environ. Res. Publ. Health. - 2009. - № 6. - P. 678-693. https://doi.org/10.3390/ijerph6020678. 